\title{
IgG and fibrinogen driven nanoparticle aggregation
}

\author{
Risto Cukalevski ${ }^{1}$, Silvia A. Ferreira ${ }^{2}$, Christopher J. Dunning ${ }^{1,3}$, Tord Berggård ${ }^{4}$, and Tommy Cedervall ${ }^{1}(\varangle)$ \\ ${ }^{1}$ Department of Biochemistry and Structural Biology, Centre for Molecular Protein Science, Chemical Centre, Lund University, PO Box 124, \\ SE-22100, Lund, Sweden \\ ${ }^{2}$ Centre for Biological Engineering, University of Minho, Campus Gualtar, 4710-057 Braga, Portugal \\ ${ }^{3}$ Neuronal Survival Unit, Department of Experimental Medical Science, Wallenberg Neuroscience Center, Lund University, BMC B11, \\ 22184, Lund, Sweden \\ ${ }^{4}$ Alligator Bioscience $A B$, Lund, Sweden
}

Received: 21 July 2014

Revised: 2 March 2015

Accepted: 5 April 2015

(c) Tsinghua University Press and Springer-Verlag Berlin Heidelberg 2015

\section{KEYWORDS}

nanoparticles (NPs), protein, corona, aggregation, immunoglobulin

\begin{abstract}
A thorough understanding of how proteins induce nanoparticle (NP) aggregation is crucial when designing in vitro and in vivo assays and interpreting experimental results. This knowledge is also crucial when developing nano-applications and formulation for drug delivery systems. In this study, we found that extraction of immunoglobulin $\mathrm{G}$ ( $\mathrm{IgG}$ ) from cow serum results in lower polystyrene NPs aggregation. Moreover, addition of isolated IgG or fibrinogen to fetal cow serum enhanced this aggregation, thus demonstrating that these factors are major drivers of NP aggregation in serum. Counter-intuitively, NP aggregation was inversely dependent on protein concentration; i.e., low protein concentrations induced large aggregates, whereas high protein concentrations induced small aggregates. Protein-induced NP aggregation and aggregate size were monitored by absorbance at $400 \mathrm{~nm}$ and dynamic light scattering, respectively. Here, we propose a mechanism behind the protein concentration dependent aggregation; this mechanism involves the effects of multiple protein interactions on the NP surface, surface area limitations, aggregation kinetics, and the influence of other serum proteins.
\end{abstract}

\section{Introduction}

Many nanoparticles have the tendency to aggregate in physiologically relevant buffers. This becomes a fundamental problem hindering systematic and reproducible studies of the characteristics and effects of nanoparticles. In physiological environments, there are usually large varieties of proteins in high concentrations, which can either stabilize nanoparticle (NP) dispersion or induce aggregation. Therefore, adding proteins to experimental systems can further complicate these studies. Thus, a thorough understanding of how proteins influence nanoparticles is necessary for evaluation of their effects regarding nanosafety and nanotoxicology and in the development of nano-applications for use in physiological environments.

Address correspondence to tommy.cedervall@biochemistry.lu.se 
In a complex biological environment (e.g., human blood, lung fluid, or cell medium), proteins will-in competition with each other-bind to the NP surface, forming a protein corona [1-9]. The protein corona changes over time $[2,4,10,11]$ depending on the surrounding protein concentration $[3,12]$ and their affinities for the NP surface. The fate depends both on the size, charge and material of the NPs and which protein it interacts with; thus, isolated proteins may or may not induce NP aggregation.

No aggregation has been detected in previous studies using silica NPs mixed with human carbonic anhydrase, cytochrome C, or ribonuclease A [13-15]. The same trend has been observed for transferrin or serum albumin mixed with sulfonated polystyrene NPs [16, 17], while other studies show that gold NPs are stabilized by serum albumin and cytochrome $\mathrm{C}$ [18-21]. Lysozyme, however, can induce the strong aggregation of silica, polystyrene, and gold NPs $[17,22-25]$, which also is observed when fibrinogen is incubated with polystyrene and silica NPs [26]. Interestingly, fibrinogen induces aggregation of poly(acrylic acid)-conjugated gold NPs [27] in a protein concentration-dependent manner. Titanium dioxide NPs can form large micrometer-sized aggregates in many protein-containing fluids [1], while other metal oxides- $-\mathrm{Fe}_{2} \mathrm{O}_{3}, \mathrm{ZnO}$, and surface functionalized $\mathrm{Fe}_{3} \mathrm{O}_{4}$, for example-are instead stabilized by serum proteins [28-30]. Polystyrene NPs in blood plasma induce large, nanometer-sized complexes, probably consisting of proteins and multiple particles [3, 12]. Gold NPs induce large, nano-sized aggregates without indication of particle agglomeration $[2,5]$, implying that proteins can serve as a link between particles. The aggregation of NPs in blood plasma or serum also depends on particle size, protein concentration, incubation time, and buffer composition $[3,5,8,9,11,12,31,32]$.

Immunoglobulin $\mathrm{G}$ (IgG) - the second most abundant protein in human blood plasma and extracellular fluid-is an antibody isotype vital for immune system function. Here, it binds pathogens resulting in their immobilization and agglutination, coats the pathogen surfaces (opsonization) allowing their recognition and phagocytosis, activates the classical pathway of the complement system, and binds and neutralizes toxins. Despite its role in the immune system and importance in many medical applications, IgG is rarely used as a model protein in protein-NP interactions.

Knowledge of how different proteins affect NP aggregation is important when designing and interpreting any experiment that involves both proteins and nanoparticles, for example, protein binding, in vitro and in vivo assays, and formulation of medical delivery systems.

In this study, we investigated protein-induced $\mathrm{NP}$ aggregation and found that IgG induces NP aggregation in a counter-intuitive concentrationdependent manner and also drives NP aggregation in blood serum. This process is dependent on the NP material, the protein, and the environment.

\section{Experimental}

\subsection{NPs and proteins}

Polystyrene (PS) and polymethyl methacrylate (PMMA) NPs were purchased from Bangs Laboratories, Inc. (Fisher, IN, USA). Two PS NPs with different surface modifications were used: sulfonated $\left(\mathrm{PS}-\mathrm{OSO}_{3} \mathrm{H}\right)$ and carboxylated (PS-COOH). The mean hydrodynamic diameter-measured by dynamic light scattering (DLS) using a Malvern Zeta NANO ZS (Malvern Instrument

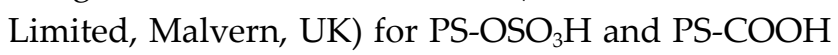
NPs is $27 \mathrm{~nm}$ (Table S1 and S2 in the Electronic Supplementary Material (ESM)). PS-OSO ${ }_{3} \mathrm{H}$ and PS$\mathrm{COOH}$ NPs have a Zeta potential of around $-45 \mathrm{mV}$ [33]. Mannan nanogel was synthesized as previously described [34] with near neutral charge and mean hydrodynamic diameter of $154 \mathrm{~nm}$. Human IgG was purchased from Lee Biosolutions (St. Louis, MO, USA). $F_{C}$ and Fab fragments from human IgG were purchased from Meridian Life Science, Inc. (Memphis, TN, USA). Human fibrinogen and fatty acid free human serum albumin (HSA; A3782) were purchased from SigmaAldrich (St. Louis, MO, USA). The HSA monomer was purified from dimers and oligomers as previously described [17]. Different qualities of fibrinogen, with respect to purity, were tested and differing results were obtained for these: F4883: 35\%-65\% protein, $\geqslant 90 \%$ which is clottable; or F3879: $50 \%-70 \%$ protein, $\geqslant 80 \%$ of protein is clottable. Both were purchased from Sigma-Aldrich. The presented data is from 
the highest quality tested (F4883). Cow serum was purchased from Innovative Research (Novi, MI, USA). All dilutions of NPs, proteins, and serum were made in PBS ( $\mathrm{pH} 7.5 ; 10.1 \mathrm{mM} \mathrm{Na} \mathrm{HPO}_{4}, 137 \mathrm{mM} \mathrm{NaCl}$, $2.7 \mathrm{mM} \mathrm{KCl}, 1.8 \mathrm{mM} \mathrm{KH}_{2} \mathrm{PO}_{4}$ ).

\subsection{IgG purification}

Bovine IgG was purified from cow serum, (Innovative research, IBV-SER) using affinity chromatography on Pierce Protein A/G Plus Agarose column (Fisher Scientific AB, 20423; Fisher Scientific AB, Waltham, MA, USA). The cow serum was filtered through a 1.2- $\mu \mathrm{m}$ filter before it was added to the PBS-washed column (Fig. S1, step 1, in the ESM) and incubated at room temperature for 25-30 $\mathrm{min}$ (Fig. S1, step 2, in the ESM). Thereafter, the cow serum was collected (same volume as was applied to the column) and non-IgG material was washed with PBS until $A_{280}$ was close to zero (Fig. S1, step 3, in the ESM). Then, $0.1 \mathrm{M}$ glycine $\mathrm{pH} 2.5$ was applied to dissociate the Protein A/G-IgG interaction and the eluate was collected into tubes containing $1 \mathrm{M}$ Tris- $\mathrm{HCl} \mathrm{pH} 8.8(120 \mu \mathrm{L} / 1 \mathrm{~mL}$ fraction $)$ (Fig. S1, step 4, in the ESM). The tubes were monitored at $A_{280}$ and the fractions containing IgG with highest absorbance was pooled and dialyzed against PBS (Fig. S2(a) in the ESM). The cow serum eluted after incubation was applied to the column for a second time and the same purification procedure was repeated (Fig. S1, step 1-4, in the ESM). SDS-PAGE was used to characterize the cow serum before and after IgG was removed and also to assess the IgG purity. The samples were incubated and heated at $95^{\circ} \mathrm{C}$ with mercaptoethanol before loading on the gel (Fig. S2(b) in the ESM).

\subsection{Aggregation measured by UV spectroscopy}

NP aggregation was monitored by measuring absorbance at $400 \mathrm{~nm}$ on an UV-1800 UV spectrometer (Shimadzu, Japan). At this wavelength, the turbidity of the sample is measured (i.e. how much light is scattered by particles in the solution). At the concentrations used, neither NPs nor proteins absorbed significantly at $400 \mathrm{~nm}$. However, some absorbance was recorded at high protein concentrations. This value was subtracted from that of the formed aggregates.
Before measurements were taken, $150 \mu \mathrm{L}$ of NPs PS-OSO ${ }_{3} \mathrm{H}, \mathrm{PS}-\mathrm{COOH}, \mathrm{PMMA}$, or mannan nanogel at a concentration of 1 or $0.5 \mathrm{mg} / \mathrm{mL}$ were mixed with $1.35 \mathrm{~mL}$ IgG, HSA, a mixture of HSA/IgG, IgG Fc fragments, IgG Fab fragments, fibrinogen, or lysozyme. The protein concentrations varied between 0.005 and $5 \mathrm{mg} / \mathrm{mL}$, as indicated in the tables and figures. Aggregation in cow serum or fetal calf serum (FCS) was achieved by mixing serum dilutions with PS$\mathrm{OSO}_{3} \mathrm{H}$. In some experiments, IgG was added to the FCS before adding NPs. The final concentration of serum, added IgG, and NPs are indicated in the text and figure labels. The mixtures were incubated for at least $1 \mathrm{~h}$ before the absorbance was monitored at $400 \mathrm{~nm}$. The experiments were performed in at least triplicates. The same conditions were used for kinetics experiments, but the absorbance at $400 \mathrm{~nm}$ was measured immediately, with a lag time of 5 to $10 \mathrm{~s}$, and then every $5 \mathrm{~s}$ for 10 to $20 \mathrm{~min}$. The time at which half of the aggregation was completed, as measured by the absorbance, was determined by fitting the equation

$$
\mathrm{Abs}=\mathrm{Abs}_{0}+\frac{\mathrm{Abs}_{\max } \cdot t}{t_{1 / 2}+t}
$$

where Abs is the absorbance at $400 \mathrm{~nm}, \mathrm{Abs}_{0}$ is the absorbance at $400 \mathrm{~nm}$ at time zero, $\mathrm{Abs}_{\max }$ is the absorbance at $400 \mathrm{~nm}$ when the steady state is reached, $t$ is the time in seconds, and $t_{1 / 2}$ is the time in seconds when half of the reaction is completed.

\subsection{Size of the aggregates measured with DLS}

The hydrodynamic diameter of NPs and protein/NP mixtures was determined by DLS using a Malvern Zeta NANO ZS. The reported hydrodynamic diameter results from size distribution analysis. Before measurements were taken, human IgG, HSA, a mixture of HSA/IgG, or human fibrinogen in PBS were incubated with $27 \mathrm{~nm} \mathrm{PS}-\mathrm{OSO}_{3} \mathrm{H}$ or PS-COOH NPs in PBS for at least $1 \mathrm{~h}$ at $23^{\circ} \mathrm{C}$. The final NPs concentration was $0.05 \mathrm{mg} / \mathrm{mL}$. Protein concentration varied from 0.005 to $3 \mathrm{mg} / \mathrm{mL}$, as indicated in tables and figures. The results are presented as the mean of at least three measurements. To evaluate the influence of different buffers on the NP size, DLS measurements were performed in PBS and $10 \mathrm{mM}$ HEPES buffer, $150 \mathrm{mM}$ 
$\mathrm{NaCl}, \mathrm{pH}$ 7.4. The NP size was the same in both buffers (data not shown).

\subsection{Circular dichroism (CD) spectroscopy and} intrinsic tryptophan fluorescence spectroscopy

Different concentrations of $\mathrm{PS}_{-} \mathrm{OSO}_{3} \mathrm{H}, \mathrm{PS}-\mathrm{COOH}$, or mannan nanogel diluted in PBS with $0.1 \mathrm{mM}$ EDTA were mixed with proteins dissolved in the same solution. NPs were added to the protein solution and incubated for $30 \pm 5$ min before recording spectra. The CD signal was recorded between 260 and $200 \mathrm{~nm}$ in a quartz (QS) cuvette with $1 \mathrm{~mm}$ path length at $37^{\circ} \mathrm{C}$ using a Jasco J-815 CD spectrometer (Jasco Analytical Instruments, Easton, MD, USA). The scanning rate was $50 \mathrm{~nm} / \mathrm{min}$, the digital integration time per data point (DIT) was $8 \mathrm{~s}$, and the data collected were from an average of five accumulations.

The fluorescence emission spectrum was recorded at $37^{\circ} \mathrm{C}$ in 10 or $3 \mathrm{~mm}$ QS cuvettes using a Perkin-Elmer LS $50 \mathrm{~B}$ luminescence spectrometer (Perkin-Elmer, Waltham, MA, USA) between 310 and $420 \mathrm{~nm}$ after excitation at $290 \mathrm{~nm}$ at a scan rate of $50 \mathrm{~nm} / \mathrm{min}$. The excitation and emission slits were set to $3 \mathrm{~nm}$. The data collected was from an average of three accumulations and the background signal from the NPs was subtracted from the overall read. Samples were handled in the same way as in the CD spectroscopy experiments.

Identical NPs titrations into protein-free buffer, PBS with $0.1 \mathrm{mM}$ EDTA were performed, and the CD and fluorescence signals were recorded. In the case of fluorescence, these data were used for baseline subtraction from the protein-NPs data. Typically, the $\mathrm{CD}$ signal-to-noise ratio was higher in the presence than in the absence of proteins. Therefore, the CD results are reported without subtracting the background signal.

\subsection{Light microscopy}

Aggregates were imaged in a clear 96-well plate (Nunc, Rochester, NY, USA) using an Olympus IX71 microscope (Olympus, Tokyo, Japan). Images were acquired using Olympus cellSens digital imaging software.

\section{Results and discussion}

To investigate if IgG was responsible for inducing $\mathrm{NP}$ aggregation in blood serum, $\mathrm{PS}_{-} \mathrm{OSO}_{3} \mathrm{H}$ NPs were incubated in FCS, cow serum, or cow serum depleted of bovine IgG by affinity chromatography (Fig. S1 in the ESM). If IgG is responsible for NP aggregation, less aggregation would be expected in FCS as compared to that for cow serum and cow serum without IgG. FCS was selected because the biological impact of NPs is often evaluated by studying human cell cultures with FCS in the growth medium. Indeed, strong aggregation was seen in diluted cow serum, with less aggregation observed in IgG-depleted cow serum as monitored by measuring the absorbance at $400 \mathrm{~nm}$ (Fig. 1(a)). Strikingly, no aggregation was seen in FCS, regardless the serum concentration (Fig. 1(a)). This demonstrated that NP aggregation in cow serum decreased as the serum concentration increased, indicating that other proteins or biomolecules might inhibit NP aggregation in high serum concentrations. Thus, many problems experienced in cell experiments performed at low serum concentrations may be absent in full blood. Increasing the NPs concentration in 1\% serum revealed that the aggregation is clearly particle concentration-dependent (Fig. 1(b)). Cow serum induced highest NP aggregation at all concentrations, and FCS lowest, whereas IgG-depleted cow serum yielded an intermediate aggregation. Adding isolated bovine IgG to FCS and IgG-depleted cow serum restored this aggregation (Fig. 1(c)). These results strongly indicate that $\mathrm{IgG}$ is an important factor driving $\mathrm{PS}^{-} \mathrm{OSO}_{3} \mathrm{H}$ aggregation in serum. Therefore, $\mathrm{NP}$ aggregation with isolated bovine IgG was investigated. As shown in Fig. 1(d), NP aggregation is dependent on the protein concentration. Samples at different IgG:NP ratios were also imaged with light microscopy (Fig. S3 in the ESM). At low absorbance (NP only, few or many IgG/NP) no or few small visible aggregates were observed (Figs. S3(a)-S3(c) and S3(f) in the ESM), whereas visible aggregates become more pronounced at higher absorbance (Figs. S3(d) and S3(e) in the ESM). This corresponds to the absorbance profiles at $400 \mathrm{~nm}$ (Fig. 1(d)).

Next, we investigated IgG-driven NP aggregation 

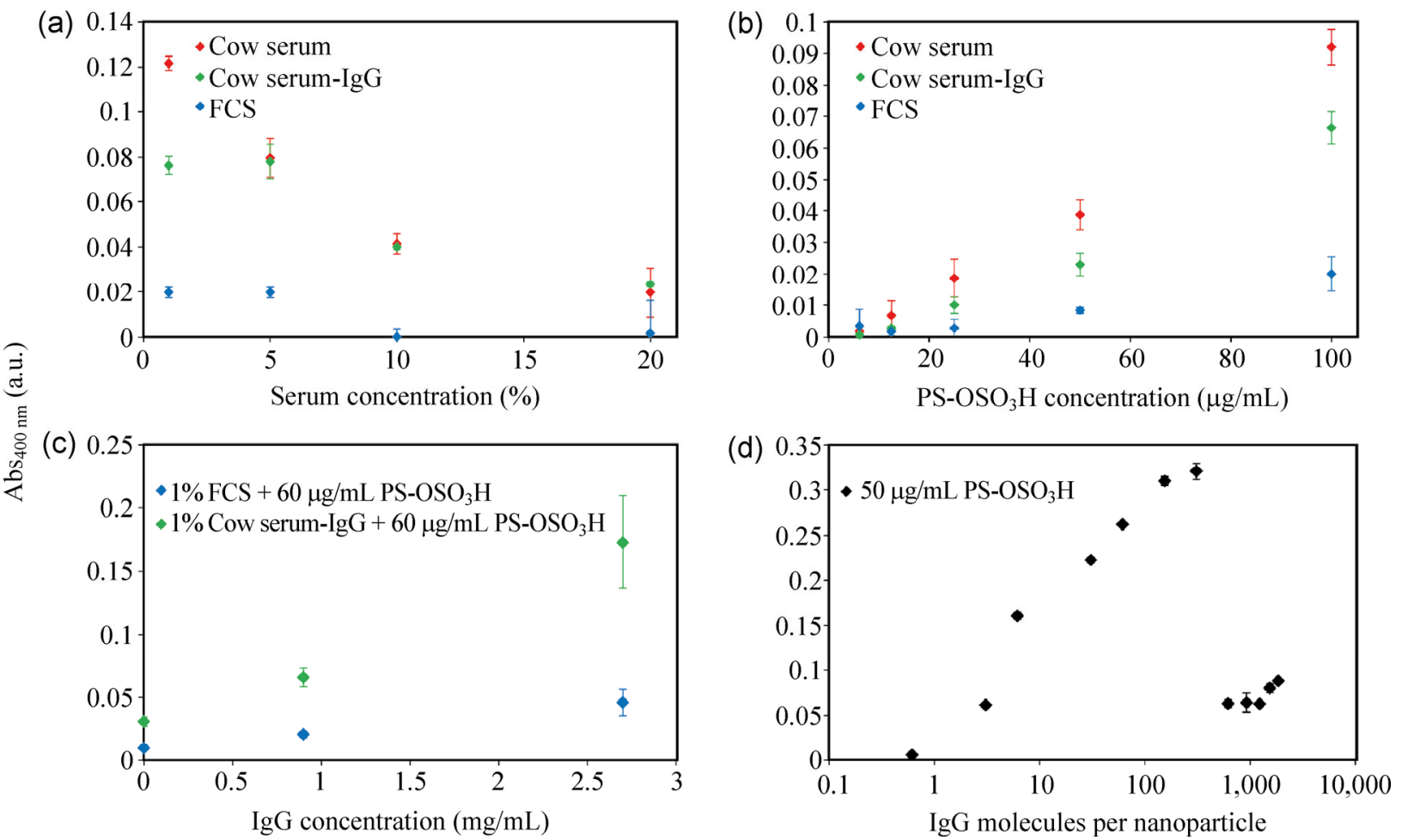

Figure 1 (a) $\mathrm{PS}-\mathrm{OSO}_{3} \mathrm{H}$ was mixed with increasing concentrations of cow serum (red), IgG-depleted cow serum (green), or FCS (blue) and the absorbance at $400 \mathrm{~nm}$ was measured. The final NP concentration was $50 \mu \mathrm{g} / \mathrm{mL}$. (b) $1 \%$ cow serum (red), IgG-depleted cow serum (green), or FCS (blue) were mixed with increasing concentrations of PS-OSO ${ }_{3} \mathrm{H}$. (c) IgG-depleted cow serum (green) or FCS (blue) was complemented with isolated bovine IgG before $\mathrm{PS}_{-} \mathrm{OSO}_{3} \mathrm{H}$ was added. The final $\mathrm{NP}$ concentration was $60 \mu \mathrm{g} / \mathrm{mL}$. (d) $\mathrm{PS}-\mathrm{OSO} \mathrm{H}_{3} \mathrm{H}$ was mixed with increasing concentrations of isolated bovine IgG. The final NP concentration was $50 \mu \mathrm{g} / \mathrm{mL}$. All samples were incubated for at least $1 \mathrm{~h}$ before the measurement. The reported value is the mean \pm S.D. of at least 3 experiments.

in detail in PBS. Human IgG is used for the following experiments. In addition to $\mathrm{PS}-\mathrm{OSO}_{3} \mathrm{H}$, we also used PS-COOH NPs, which have different surface groups but both are negatively charged at $\mathrm{pH}$ 7.5. $\mathrm{PS}-\mathrm{OSO}_{3} \mathrm{H}$ or PS-COOH NPs were mixed with increasing concentrations of IgG (Fig. 2). The absorbance increases at around 5 to $10 \mathrm{IgG}$ molecules per NP, indicative of aggregate formation (Figs. 2(a) and 2(b)). Further increases in the number of IgG molecules failed to elicit any significant differences in absorbance until a minimum of 40 to 100 molecules was reached. Above 100 IgG molecules per NP, the absorbance decreases and the solutions become transparent, indicating that no or small aggregates formed. These results reveal an inverse correlation between the number of $\operatorname{IgG}$ molecules in the solution and the degree of aggregation, which is similar to the aggregation behavior observed with isolated bovine IgG (Fig. 1(d)). Increasing the particle concentration two-fold resulted in a similar aggregation profile (Figs. 2(a) and 2(b)). To investigate if the structural change of IgG was causing the NP aggregation, the secondary and tertiary structure were monitored with $\mathrm{CD}$ and intrinsic tryptophan fluorescence spectroscopy, respectively. Changes in the tertiary structure were observed, seen as a decrease in intensity, but no shift in the tryptophan emission was detected. The secondary structure, however, was slightly affected when IgG bound to the NPs (Fig. S4 in the ESM). This data implies that IgG denaturation was not required for the aggregation to occur.

To determine the size of the PS-OSO${ }_{3} \mathrm{H}: \mathrm{IgG}$ complexes, DLS was studied at various IgG concentrations (Fig. 2(c) and Table S1 in the ESM). At $2.8 \mathrm{IgG}$ molecules per NP, the hydrodynamic diameter of the PS-OSO ${ }_{3} \mathrm{H}: \mathrm{IgG}$ complexes was approximately $50 \mathrm{~nm}$, indicating formation of small aggregates. At $28 \mathrm{IgG}$ molecules per NP, the diameter reached over 2,000 nm, denoting large aggregates of multiple NPs and IgG 


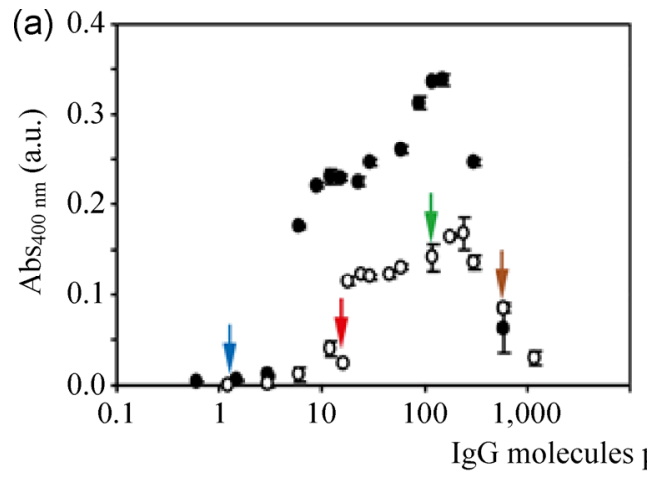

(b) 0.6
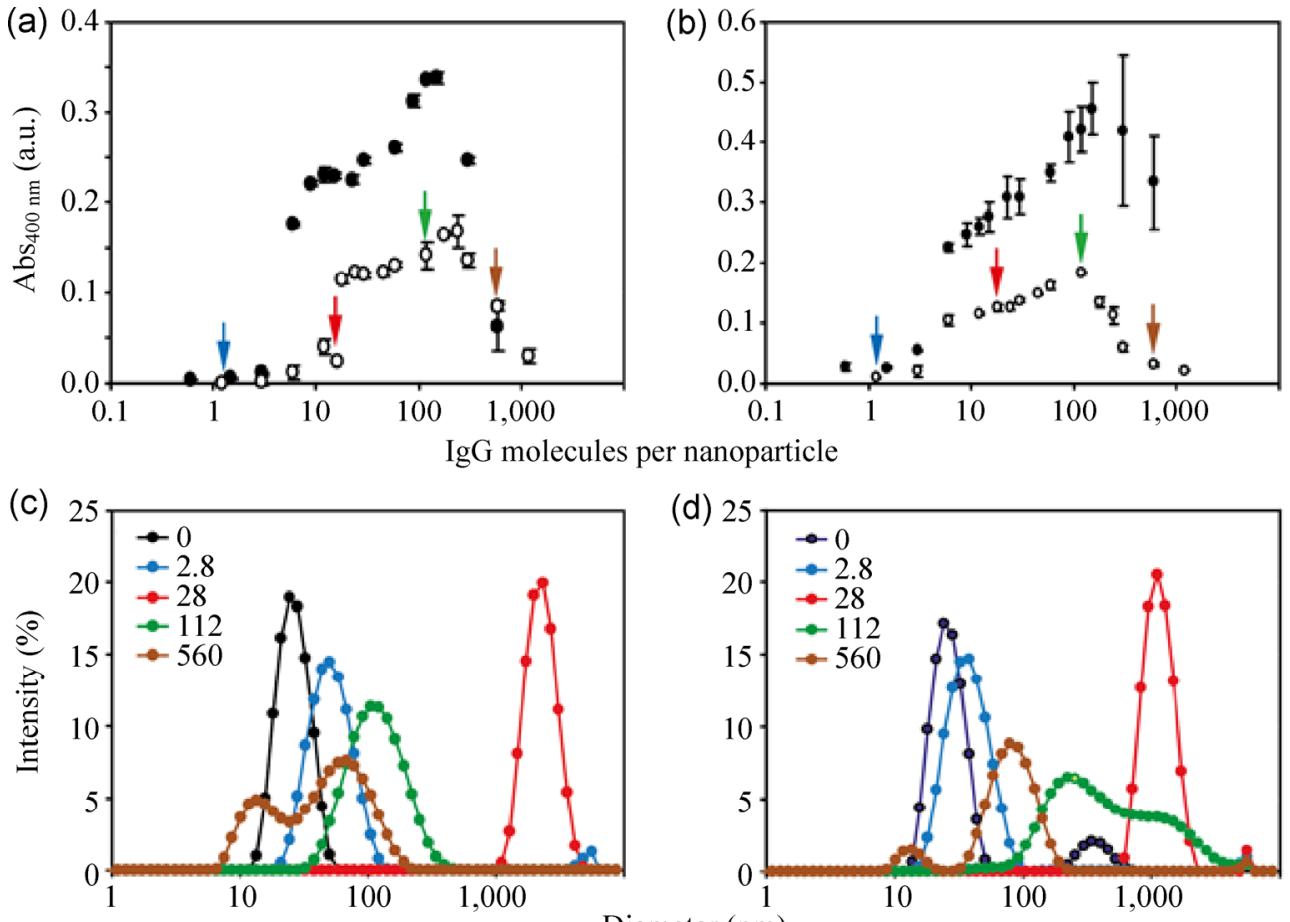

(d) 25

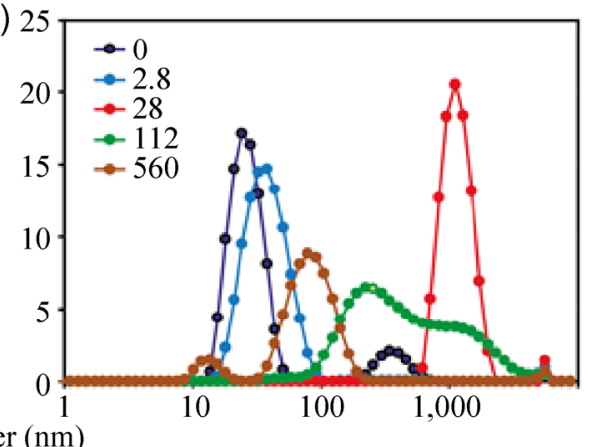

Figure 2 PS- $\mathrm{OSO}_{3} \mathrm{H}$ (a) or PS-COOH (b) NPs were mixed with different IgG concentrations and incubated for at least $1 \mathrm{~h}$ before the absorbance at $400 \mathrm{~nm}$ was measured. The final NP concentration was $0.05 \mathrm{mg} / \mathrm{mL}$ (open circles) or $0.1 \mathrm{mg} / \mathrm{mL}$ (closed circles) and the $\mathrm{IgG}$ concentration varied between 0.001 and $3 \mathrm{mg} / \mathrm{mL}$. DLS measurements for some selected $\mathrm{IgG}$ concentrations mixed with $0.1 \mathrm{mg} / \mathrm{mL}$ (c) PS-OSO ${ }_{3} \mathrm{H}$ or (d) PS-COOH NPs. The digits $0,2.8,28,112$, and 560 indicate the number of IgG molecules per NP. The reported value is the mean \pm S.D. of 3 to 9 experiments.

molecules. At 112 IgG molecules per NP, the diameter is $128 \mathrm{~nm}$ and the highest absorbance was observed. This discrepancy between absorbance and DLS data can likely be explained by a large number of aggregates. The correlation between the observed absorbance and the increase in aggregation is not straightforward. Aggregates will scatter light resulting in an increase in the apparent absorbance, which increases exponentially with aggregate size. Therefore, an increase in the number of aggregates or in the size of aggregates will change the observed absorbance differently. At $560 \mathrm{IgG}$ molecules per NP, two peaks corresponding to 15 and $70 \mathrm{~nm}$ in diameter, where the smaller probably represents unbound IgG. DLS data (Fig. 2(d) and Table S2 in the ESM) of PS-COOH confirms that this IgG-driven aggregation is similar to the one observed with $\mathrm{PS}-\mathrm{OSO}_{3} \mathrm{H}$ NPs.

A possible explanation behind the IgG-induced aggregation is that IgG acts or serves as a protein bridge between NPs to form large aggregates. However, bridging can only occur if there is more than one surface to which IgG can bind. Limited digestion of IgG by papain produces $\mathrm{Fc}$ and $\mathrm{Fab}$ fragments (Scheme 1). Adding PS-OSO $\mathrm{O}_{3} \mathrm{H}$ or PS-COOH NPs to FC induced minor changes in the CD spectra, while Fab slightly affected the intrinsic tryptophan fluorescence spectra (Figs. S5 and S6 in the ESM). This indicates that both Fc and Fab interact with the NPs. Furthermore, addition of $\mathrm{Fc}$ to PS-COOH induced concentrationdependent NP aggregation, similar to what is observed with IgG, indicating that Fc interacts with the NPs with at least two binding sites. In contrast, the addition of Fab fragments failed to induce PS-COOH

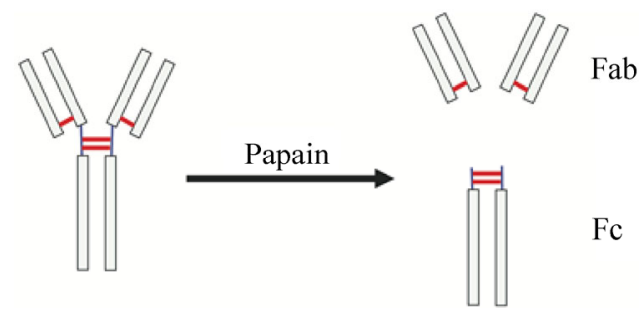

Scheme 1 Fc and Fab fragments obtained after cleavage of IgG with papain. 
NP aggregation (Fig. S7 in the ESM). A large excess of Fab could likely induce a small amount of aggregation, probably due to Fc impurities in the Fab preparation (data not shown). This implies that the NP aggregation is not driven by major structural changes.

PMMA NPs likewise aggregate with increasing concentrations of IgG (Fig. S8 in the ESM). Interestingly, the aggregation profile is similar to those obtained with $\mathrm{PS}_{-} \mathrm{OSO}_{3} \mathrm{H}$ and PS-COOH. In contrast, IgG failed to induce the aggregation of mannan nanogel (data not shown). However, the changes in $\mathrm{CD}$ and mainly in the intrinsic tryptophan fluorescence spectra of IgG after the addition of mannan nanogel strongly indicated that IgG bound to the nanogel (Fig. S9 in the ESM), does not automatically result in particle aggregation.

The NP aggregation induced by fibrinogen is, as for IgG, dependent on the protein concentration (Fig. 3(a)).

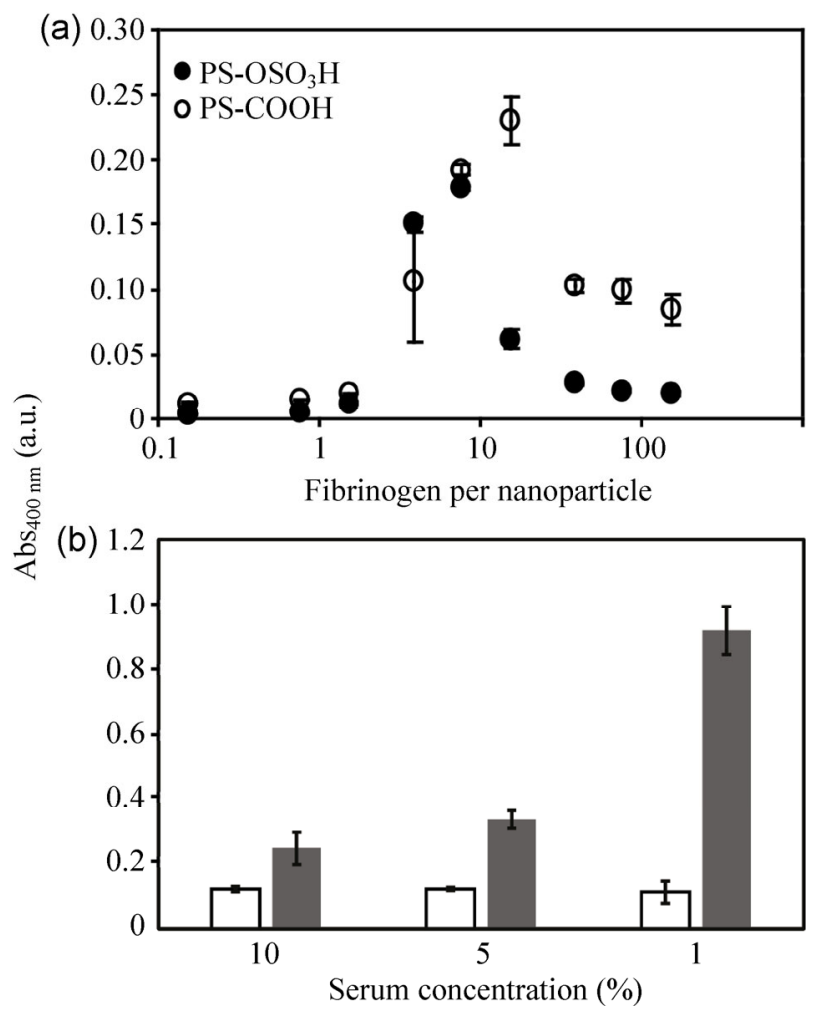

Figure 3 Fibrinogen driven aggregation of $27 \mathrm{~nm} \mathrm{PS-OSO} \mathrm{P}_{3} \mathrm{H}$ and PS-COOH NPs. (a) The final NP concentration was $0.1 \mathrm{mg} / \mathrm{mL}$. The fibrinogen concentrations varied between 0.001 and $5 \mathrm{mg} / \mathrm{mL}$. (b) $\mathrm{PS}-\mathrm{OSO}_{3} \mathrm{H}$ NPs were mixed with different concentrations of FCS without (white bars) or with added human fibrinogen $(0.083 \mathrm{mg} / \mathrm{mL}$, grey bars). The samples were incubated for at least $1 \mathrm{~h}$ before aggregation was measured. The reported value is the mean \pm S.D. of 3 experiments.
In contrast to IgG, there are large structural changes in fibrinogen that occur after binding to the NPs (Fig. S10 in the ESM). DLS data show that the mean hydrodynamic diameter of the formed aggregates follows the same pattern as for IgG (Table S3 in the ESM). Large aggregates form at low fibrinogen concentrations but, at high fibrinogen concentrations, the

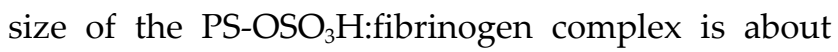
$75 \mathrm{~nm}$. Adding fibrinogen to FCS also induces the strong aggregation of $\mathrm{PS}_{-} \mathrm{OSO}_{3} \mathrm{H}$ NPs (Fig. 3(b)). The fibrinogen concentration in serum is close to $3 \mathrm{mg} / \mathrm{mL}$ in plasma and uncoagulated blood; therefore, fibrinogen together with IgG is probably the primary driver of NP aggregation in blood. The same concentration dependent fibrinogen-induced aggregation in buffer was previously shown for polyacrylic acidconjugated gold NPs [27]. The authors suggest that when there is an excess of particle surface, fibrinogen acts as a bridge between them to form large aggregates but, when there is an excess of fibrinogen, the NP surface is rapidly covered by protein to prevent bridging between the NPs.

Our data on the $\mathrm{IgG}$-driven aggregation of $\mathrm{PS}^{-} \mathrm{OSO}_{3} \mathrm{H}$, PS-COOH, and PMMA NPs supports the proposed mechanism. We suggest that the important features of protein concentration-dependent aggregation can be described by considering four regimes (Scheme 2). In the first regime, there is a large excess of NPs resulting in a mixture of empty NPs, NPs with one $\mathrm{IgG}$, and small aggregates where $\operatorname{IgG}$ functions as a bridge between two NPs. In the second regime, there are more IgG molecules per NP but still an excess of NP surface; therefore, one $\operatorname{IgG}$ molecule already bound to a NP can still bind to more than one NP and bridging can occur in many different directions to generate large aggregates. In the third, there is less available surface area and finding an empty area on a second NP for IgG to bind will take longer time, and therefore more smaller aggregates form. In the fourth regime, there is a large excess of IgG, leading to a decrease in aggregation because the NP surface becomes rapidly covered by IgG. Thus, at very high protein concentrations, no particle aggregation occurs since single particles are quickly covered by a protein monolayer. 


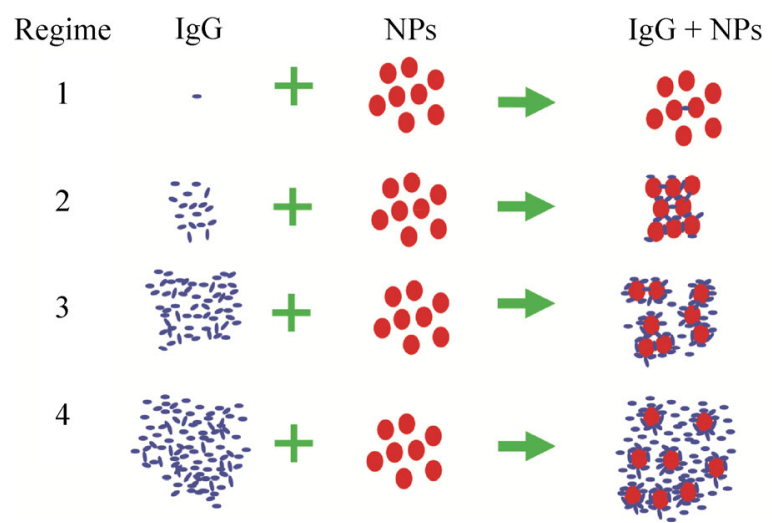

Scheme 2 Aggregation of PS and PMMA NPs with increasing IgG concentration. Aggregates of different sizes are formed depending on the ratio of $\operatorname{IgG}$ and available surface area.

The described mechanism can be validated with two predictions. First, reducing the available surface area should decrease the size of the aggregates. As shown above, the NP aggregation is lower in high concentrations of blood serum than that in low concentrations (Fig. 1). This indicates that there are substances in serum that inhibit NP aggregation, which implies that the first prediction is correct. Albumin is a likely candidate, as it is the most abundant protein in blood serum, binds to $\mathrm{PS}-\mathrm{OSO}_{3} \mathrm{H}$ and $\mathrm{PS}-\mathrm{COOH}$ [17], and cannot by itself induce particle aggregation (data not shown). Indeed, adding HSA to the PS-COOH NP before adding IgG reduces the NP absorbance (Fig. 4(a)) and the diameter of the formed aggregates (Fig. 4(b)) compared to that with IgG alone. Interestingly, the aggregation profile is still dependent on the $\mathrm{IgG}$ concentrations (Fig. 4(c)). The order of adding HSA and IgG to the NPs is important since adding the same amount of HSA to IgG prior to adding PS-COOH NPs to the protein mixture increases the absorbance compared to first adding HSA to the particles (Fig. 4(d)). This implies that the system is kinetically, rather than thermodynamically, driven over the time period of our experiments. Another way to reduce the surface area is to keep the added mass and increase the NP size. The addition of same amount of IgG to $60 \mathrm{~nm}$ PS-COOH NPs shifts the aggregation profile compared to $26 \mathrm{~nm}$ NPs (Fig. S11 in the ESM). As expected, less
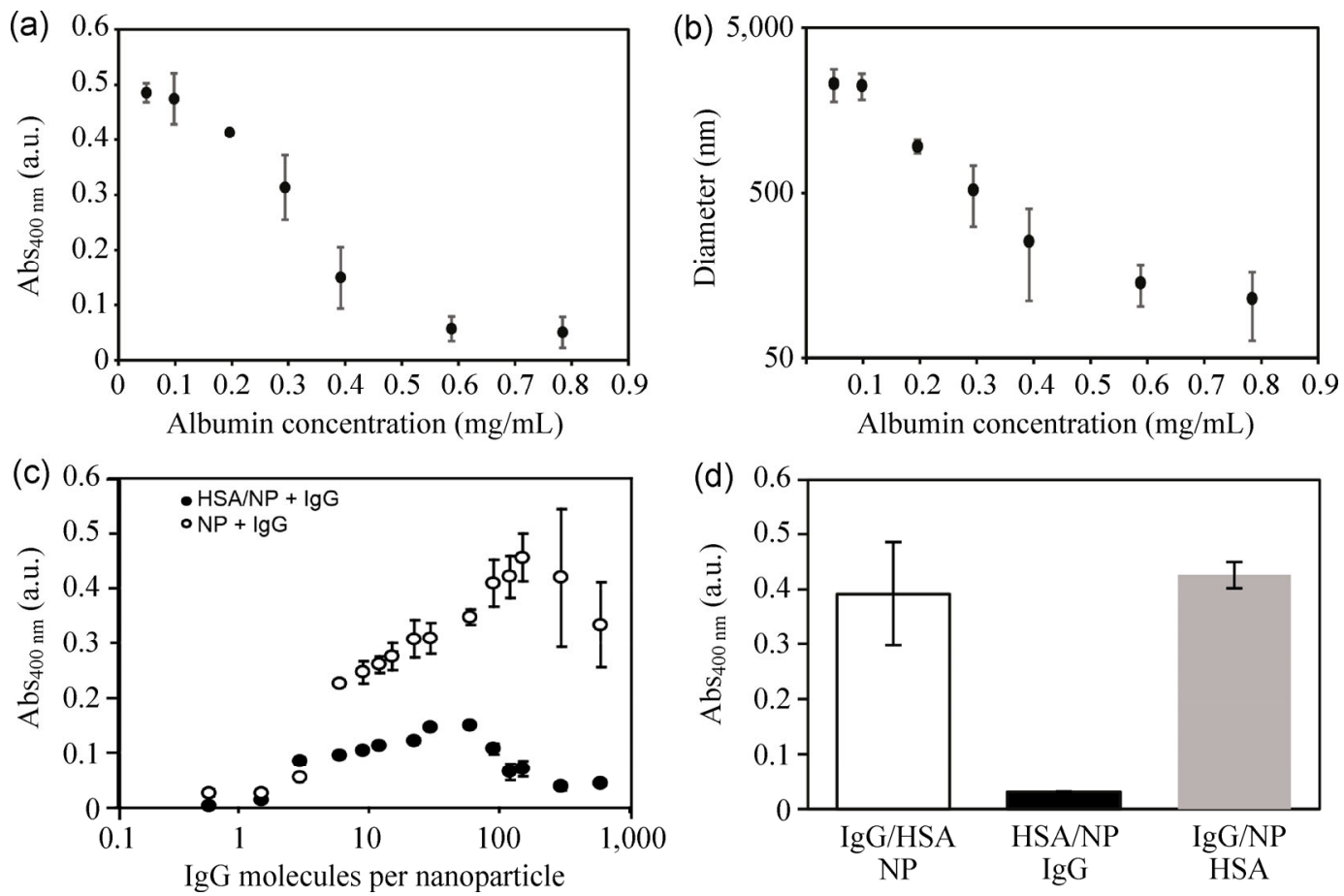

Figure 4 IgG-driven aggregation of PS-COOH NPs in the presence of HSA. (a) and (b) HSA was mixed with PS-COOH NPs before IgG was added and (a) the absorbance at $400 \mathrm{~nm}$ was measured or (b) the hydrodynamic diameter was measured by DLS. The final NP and IgG concentrations were 0.1 and $0.4 \mathrm{mg} / \mathrm{mL}$, respectively. (c) IgG was mixed with PS-COOH NPs or NPs pre-incubated with HSA and the absorbance was measured. The IgG concentration ranged between 0.001 and $3 \mathrm{mg} / \mathrm{mL}$ and the final NP and HSA concentrations were $0.1 \mathrm{mg} / \mathrm{mL}$, (d) NPs were mixed with a premix of IgG/HSA (white bar), premixed with HSA and then IgG (grey bar), or premixed with IgG and then HSA (black bar). The reported value is the mean \pm S.D. of 3 experiments. 
amount of $\operatorname{IgG}$ is required to reduce the aggregation of the $60 \mathrm{~nm}$ NP (Fig. S11(a) in the ESM) as the total surface area is smaller. Furthermore, the number of IgG per NP needed to reduce the aggregation is higher since the surface area per NP is larger (Fig. S11(b) in the ESM). These experiments further strengthen the importance of the relationship between available surface area and the IgG-driven aggregation.

The second prediction is that the kinetics of the formation of larger aggregates should become retarded with increasing IgG concentrations. To verify this, the aggregation kinetics of $\mathrm{PS}^{-} \mathrm{OSO}_{3} \mathrm{H}$ and $\mathrm{PS}-\mathrm{COOH}$ NPs mixed with IgG were studied by following the absorbance over time at $400 \mathrm{~nm}$. Note that the aggregation process is followed for 1,200 s compared to $1 \mathrm{~h}$ or more in the previous measurements, and is the main reason why the absorbance might differ at the same IgG:NP ratios between the experiments. The lag time between mixing and the first reading is about $5 \mathrm{~s}$. Examples of interesting differences in kinetics are shown in Figs. 5(a) and 5(b). The time point at which half of the process in this time range is completed, $t_{1 / 2}$, was extracted from Eq. (1) by fitting that function to the experimental data (Figs. 5(c) and 5(d)). At IgG concentrations corresponding to 10 to 50 IgG molecules per NP, the aggregation was fast. Adding more IgG decreases the aggregation rate indicating that the second prediction is correct, (i.e., the kinetics of the aggregate formation slows down as the available surface area becomes limited). However, at the highest IgG concentrations, the aggregation rate increases again probably because only small aggregates of one or few particles rapidly forms (see regime 4 in Scheme 2). Note that the low absorbance makes it difficult to estimate the $t_{1 / 2}$ of aggregation at high IgG concentrations.

In the last few years, attention has been drawn to the protein corona that forms around NPs. Studying the protein corona may seem to be a straightforward project. However, the aggregation profile of IgG and fibrinogen highlights the need for caution. When the NPs aggregate into large complexes in protein-rich fluid, there will be many protein bridges that form strongly associated aggregates. Other proteins with
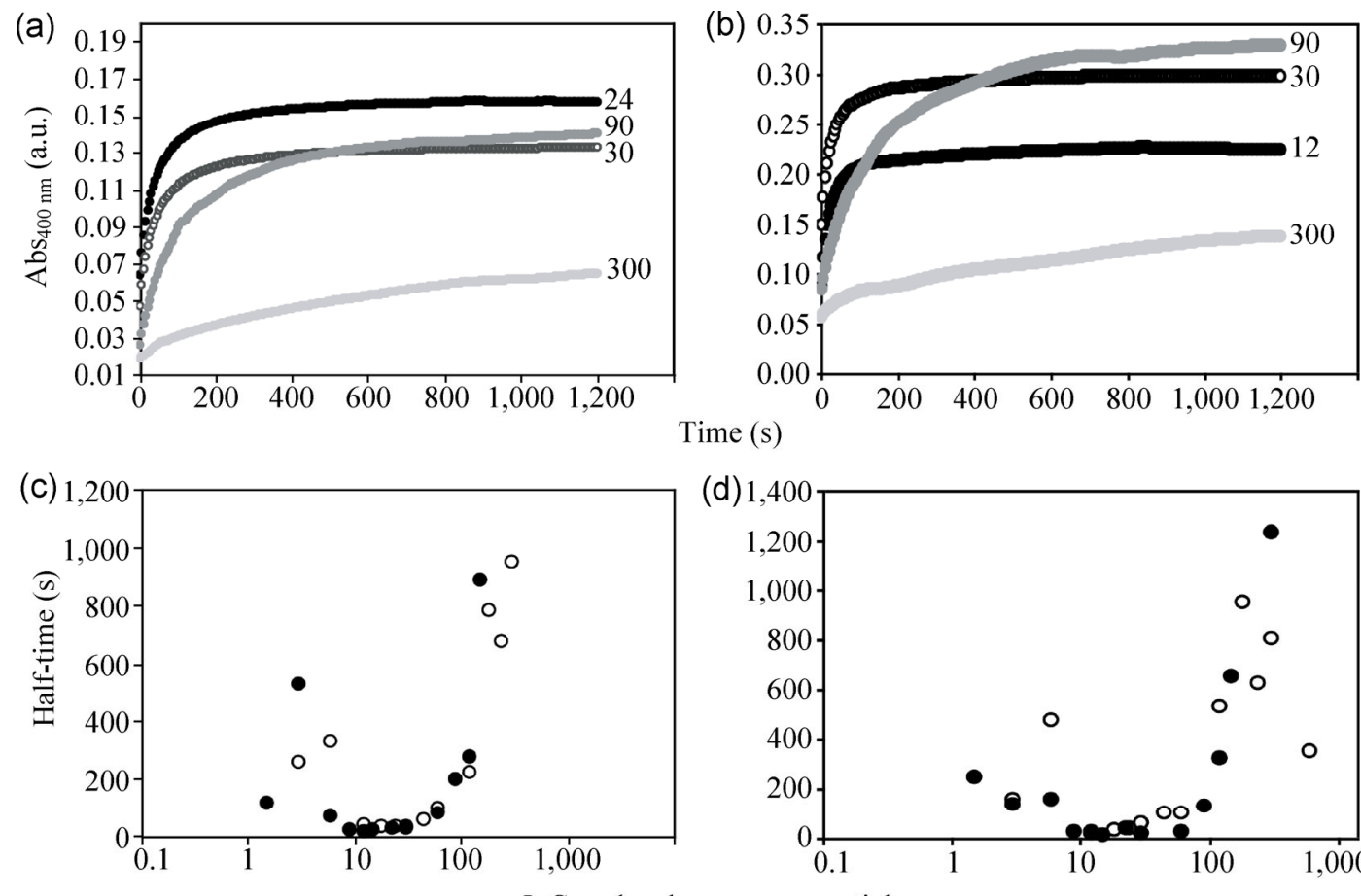

Time (s)

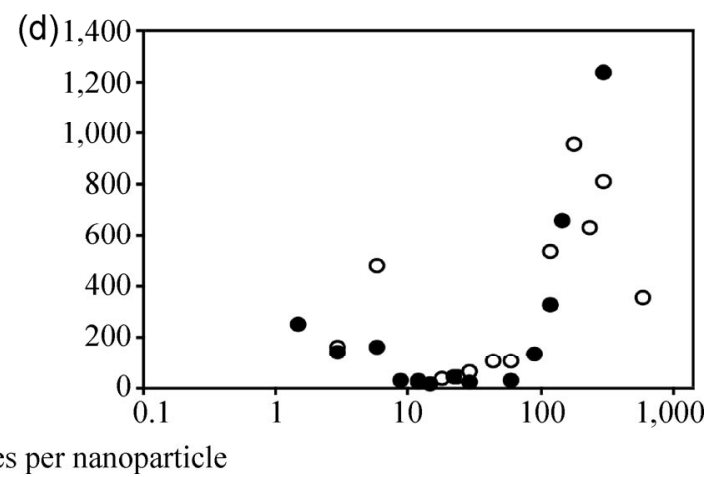

Figure 5 The aggregation kinetics of $\mathrm{PS}-\mathrm{OSO}_{3} \mathrm{H}$ (a) and of $\mathrm{PS}-\mathrm{COOH}$ (b) for some selected IgG concentrations. The digits $24,30,90$, and 300 correspond to the number of IgG molecules per NP. The final concentration of NPs was $0.05 \mathrm{mg} / \mathrm{mL}$. The half-time of aggregation for $\mathrm{PS}_{-} \mathrm{OSO}_{3} \mathrm{H}(\mathrm{c})$ and of $\mathrm{PS}-\mathrm{COOH}(\mathrm{d})$ was calculated as described in material and methods. The final NP concentration was $0.05 \mathrm{mg} / \mathrm{mL}$ (open circles) or $0.1 \mathrm{mg} / \mathrm{mL}$ (closed circles) and the IgG concentration varied between $0.001 \mathrm{and} 3 \mathrm{mg} / \mathrm{mL}$. 
no or weak affinity to the NPs may be trapped in the aggregates induced by IgG or other proteins. The bridging proteins and the trapped proteins may be interpreted as proteins with high affinity. Moreover, diluting the protein-rich fluids can alter how the proteins affect NP aggregation. Consequently, studies on any aspect of the protein corona at only one protein/NP ratio may not adequately describe the corona at physiologically relevant conditions.

Monoclonal antibodies $(\mathrm{mAb})$ are used as active compounds in many biopharmaceutical drugs and are formulated either as liquids or as lyophilized products. In recent years, there has been a considerable research interest in the area of drug delivery of mAbs using NPs. Formulating the mAb together with NPs may provide for drug delivery at a controlled and sustained rate and, consequently improve the pharmacokinetic and pharmacodynamic properties of the compound. A potential challenge with $\mathrm{mAb} / \mathrm{NP}$ formulations is that the NPs may form particle-particle aggregates, and potentially NP-mAb aggregates. It is a regulatory demand to minimize aggregates in biopharmaceutical drug products since they may cause safety problems, such as immunogenicity. In this report, we have shown that concentration-dependent IgG/NP-induced aggregation may be counter-intuitive. Although only a few NPs were investigated here, it is not unlikely that a similar behavior is observed in biopharmaceutical $\mathrm{mAb} / \mathrm{NP}$ systems also. If so, this finding may have implications for future $\mathrm{mAb} / \mathrm{NP}$ formulation development.

\section{Acknowledgements}

We thank Professor Sara Linse for scientific discussions and advice and Professor Patrik Brundin for enabling access to the light microscope. The project received financial support from Nanometer structure consortium at Lund University (nmC@LU), Lars Hierta Foundation, and the research school FLÄK of Lund University.

Electronic Supplementary Material: Supplementary material (information on the structure of proteins bound to NPs by circular dichroism spectroscopy and on aggregation of NPs other than polystyrene) is available in the online version of this article at http://dx.doi.org/10.1007/s12274-015-0780-4.

\section{References}

[1] Sund, J.; Alenius, H.; Vippola, M.; Savolainen, K.; Puustinen, A. Proteomic characterization of engineered nanomaterialprotein interactions in relation to surface reactivity. ACS Nano 2011, 5, 4300-4309.

[2] Maiorano, G.; Sabella, S.; Sorce, B.; Brunetti, V.; Malvindi, M. A.; Cingolani, R.; Pompa, P. P. Effects of cell culture media on the dynamic formation of protein-nanoparticle complexes and influence on the cellular response. ACS Nano 2010, 4, 7481-7491.

[3] Lundqvist, M.; Stigler, J.; Elia, G.; Lynch, I.; Cedervall, T.; Dawson, K. A. Nanoparticle size and surface properties determine the protein corona with possible implications for biological impacts. Proc. Natl. Acad. Sci. USA 2008, 105, 14265-14270.

[4] Ferreira, S. A.; Oslakovic, C.; Cukalevski, R.; Frohm, B.; Dahlback, B.; Linse, S.; Gama, F. M.; Cedervall, T. Biocompatibility of mannan nanogel-safe interaction with plasma proteins. Biochim. Biophys. Acta 2012, 1820, 10431051.

[5] Dobrovolskaia, M. A.; Patri, A. K.; Zheng, J.; Clogston, J. D.; Ayub, N.; Aggarwal, P.; Neun, B. W.; Hall, J. B.; McNeil, S. E. Interaction of colloidal gold nanoparticles with human blood: Effects on particle size and analysis of plasma protein binding profiles. Nanomedicine: Nanotechnology, Biology, and Medicine 2009, 5, 106-117.

[6] Cedervall, T.; Lynch, I.; Lindman, S.; Berggard, T.; Thulin, E.; Nilsson, H.; Dawson, K. A.; Linse, S. Understanding the nanoparticle-protein corona using methods to quantify exchange rates and affinities of proteins for nanoparticles. Proc. Natl. Acad. Sci. USA 2007, 104, 2050-2055.

[7] Cedervall, T.; Lynch, I.; Foy, M.; Berggard, T.; Donnelly, S. C.; Cagney, G.; Linse, S.; Dawson, K. A. Detailed identification of plasma proteins adsorbed on copolymer nanoparticles. Angew. Chem., Int. Ed. 2007, 46, 5754-5756.

[8] Walkey, C. D.; Olsen, J. B.; Guo, H.; Emili, A.; Chan, W. C. Nanoparticle size and surface chemistry determine serum protein adsorption and macrophage uptake. J. Am. Chem. Soc. 2012, 134, 2139-2147.

[9] Tenzer, S.; Docter, D.; Rosfa, S.; Wlodarski, A.; Kuharev, J.; Rekik, A.; Knauer, S. K.; Bantz, C.; Nawroth, T.; Bier, C.; Sirirattanapan, J. et al. Nanoparticle size is a critical physicochemical determinant of the human blood plasma corona: A comprehensive quantitative proteomic analysis. ACS Nano 2011, 5, 7155-7167. 
[10] Dell'Orco, D.; Lundqvist, M.; Oslakovic, C.; Cedervall, T.; Linse, S. Modeling the time evolution of the nanoparticleprotein corona in a body fluid. PloS One 2010, 5, e10949.

[11] Casals, E.; Pfaller, T.; Duschl, A.; Oostingh, G. J.; Puntes, $\mathrm{V}$. Time evolution of the nanoparticle protein corona. ACS Nano 2010, 4, 3623-3632.

[12] Monopoli, M. P.; Walczyk, D.; Campbell, A.; Elia, G.; Lynch, I.; Bombelli, F. B.; Dawson, K. A. Physical-chemical aspects of protein corona: Relevance to in vitro and in vivo biological impacts of nanoparticles. J. Am. Chem. Soc. 2011 133, 2525-2534.

[13] Shang, W.; Nuffer, J. H.; Muniz-Papandrea, V. A.; Colon, W.; Siegel, R. W.; Dordick, J. S. Cytochrome C on silica nanoparticles: Influence of nanoparticle size on protein structure, stability, and activity. Small 2009, 5, 470-476.

[14] Shang, W.; Nuffer, J. H.; Dordick, J. S.; Siegel, R. W. Unfolding of ribonuclease A on silica nanoparticle surfaces. Nano Lett. 2007, 7, 1991-1995.

[15] Lundqvist, M.; Sethson, I.; Jonsson, B. H. Protein adsorption onto silica nanoparticles: Conformational changes depend on the particles' curvature and the protein stability. Langmuir 2004, 20, 10639-10647.

[16] Pitek, A. S.; O'Connell, D.; Mahon, E.; Monopoli, M. P.; Baldelli Bombelli, F.; Dawson, K. A. Transferrin coated nanoparticles: Study of the bionano interface in human plasma. PloS One 2012, 7, e40685.

[17] Cukalevski, R.; Lundqvist, M.; Oslakovic, C.; Dahlback, B.; Linse, S.; Cedervall, T. Structural changes in apolipoproteins bound to nanoparticles. Langmuir 2011, 27, 14360-14369.

[18] Jiang, X.; Jiang, J. G.; Jin, Y. D.;Wang, E.; Dong, S. J. Effect of colloidal gold size on the conformational changes of adsorbed cytochrome C: Probing by circular dichroism, UV-visible, and infrared spectroscopy. Biomacromolecules 2005, 6, 46-53.

[19] Goy-Lopez, S.; Juarez, J.; Alatorre-Meda, M.; Casals, E.; Puntes, V. F.; Taboada, P.; Mosquera, V. Physicochemical characteristics of protein-NP bioconjugates: The role of particle curvature and solution conditions on human serum albumin conformation and fibrillogenesis inhibition. Langmuir 2012, 28, 9113-9126.

[20] Dominguez-Medina, S.; McDonough, S.; Swanglap, P.; Landes, C. F.; Link, S. In situ measurement of bovine serum albumin interaction with gold nanospheres. Langmuir 2012, 28, 9131-9139.

[21] Glomm, W. R.; Halskau, Ø.; Hanneseth, A. M.; Volden, S. Adsorption behavior of acidic and basic proteins onto citrate-coated $\mathrm{Au}$ surfaces correlated to their native fold, stability, and pI. J. Phys. Chem. B 2007, 111, 14329-14345.
[22] Zhang, D. M.; Neumann, O.; Wang, H.; Yuwono, V. M.; Barhoumi, A.; Perham, M.; Hartgerink, J. D.; WittungStafshede, P.; Halas, N. J. Gold nanoparticles can induce the formation of protein-based aggregates at physiological pH. Nano Lett. 2009, 9, 666-671.

[23] Kumar, S.; Aswal, V. K.; Kohlbrecher, J. SANS and UV-vis spectroscopy studies of resultant structure from lysozyme adsorption on silica nanoparticles. Langmuir 2011, 27, 10167-10173.

[24] Gagner, J. E.; Lopez, M. D.; Dordick, J. S.; Siegel, R. W. Effect of gold nanoparticle morphology on adsorbed protein structure and function. Biomaterials 2011, 32, 7241-7252.

[25] Bharti, B.; Meissner, J.; Findenegg, G. H. Aggregation of silica nanoparticles directed by adsorption of lysozyme. Langmuir 2011, 27, 9823-9833.

[26] Kendall, M.; Ding, P.; Kendall, K. Particle and nanoparticle interactions with fibrinogen: The importance of aggregation in nanotoxicology. Nanotoxicology 2011, 5, 55-65.

[27] Deng, Z. J.; Liang, M.; Toth, I.; Monteiro, M. J.; Minchin, R. F. Molecular interaction of poly(acrylic acid) gold nanoparticles with human fibrinogen. ACS Nano 2012, 6, 8962-8969.

[28] Wells, M. A.; Abid, A.; Kennedy, I. M.; Barakat, A. I. Serum proteins prevent aggregation of $\mathrm{Fe}_{2} \mathrm{O}_{3}$ and $\mathrm{ZnO}$ nanoparticles. Nanotoxicology 2012, 6, 837-846.

[29] Wiogo, H. T.; Lim, M.; Bulmus, V.; Yun, J.; Amal, R. Stabilization of magnetic iron oxide nanoparticles in biological media by fetal bovine serum (FBS). Langmuir 2011, 27, 843-850.

[30] Wiogo, H. T.; Lim, M.; Bulmus, V.; Gutierrez, L.; Woodward, R. C.; Amal, R. Insight into serum protein interactions with functionalized magnetic nanoparticles in biological media. Langmuir 2012, 28, 4346-4356.

[31] Zook, J. M.; Maccuspie, R. I.; Locascio, L. E.; Halter, M. D.; Elliott, J. T. Stable nanoparticle aggregates/agglomerates of different sizes and the effect of their size on hemolytic cytotoxicity. Nanotoxicology 2011, 5, 517-530.

[32] Casals, E.; Pfaller, T.; Duschl, A.; Oostingh, G. J.; Puntes, $\mathrm{V}$. F. Hardening of the nanoparticle-protein corona in metal $(\mathrm{Au}, \mathrm{Ag})$ and oxide $\left(\mathrm{Fe}_{3} \mathrm{O}_{4}, \mathrm{CoO}\right.$, and $\left.\mathrm{CeO}_{2}\right)$ nanoparticles. Small 2011, 7, 3479-3486.

[33] Oslakovic, C.; Cedervall, T.; Linse, S.; Dahlback, B. Polystyrene nanoparticles affecting blood coagulation. Nanomedicine: Nanotechnology, Biology, and Medicine 2012, 8, 981-986.

[34] Ferreira, S. A.; Pereira, P.; Sampaio, P.; Coutinho, P. J. G.; Gama, F. M. Supramolecular assembled nanogel made of mannan. J. Colloid Interf. Sci. 2011, 361, 97-108. 